\title{
Health Risk among Front Liners during COVID-19 in India: A Sociological View Point
}

\author{
Sudesh Kumar* \\ Assistant Professor of Sociology, Department of Humanities and Social Sciences, GD Goenka University, Haryana, India
}

*Corresponding author: Sudesh Kumar, Assistant Professor of Sociology, Department of Humanities and Social Sciences, GD Goenka University, Haryana, India, E-mail: aryansudesh@yahoo.com

Received: 23 Aug, 2021 | Accepted: 09 Oct, 2021 | Published: 18 Oct, 2021

Citation: Kumar S (2021) Health Risk among Front Liners during COVID-19 in India: A Sociological View Point. J Epidemiol Public Health Rev 6(4): dx.doi.org/10.16966/2471-8211.217

Copyright: () 2021 Kumar S. This is an open-access article distributed under the terms of the Creative Commons Attribution License, which permits unrestricted use, distribution, and reproduction in any medium, provided the original author and source are credited.

\begin{abstract}
The present paper is an attempt to understand the consequences of COVID-19 on front liners in India with reference to their health risk. It is based on secondary sources such as research papers/articles, media report, and newspapers. The main objective of the study is to highlight the issues and problems which the front liners are facing during the pandemic crisis. It was found that in the COVID-19 crisis, most of the front liners have been infected and many of them have lost their lives. The study has further observed that in the initial phase of COVID-19 the majority of the front liners were working without proper PPE kits which have direct impact on their health risk.
\end{abstract}

Keywords: COVID-19; Indian society; Issues, Problems; Health risk; Front liners

\section{Introduction}

In this global humanitarian crisis of the COVID-19, mental health issues have been reported from all over the world [1]. Globally, consistently high levels of stress, anxiety, depression and poor sleep were observed regardless of number of COVID-19 cases. Over $70 \%$ of the respondents had greater than moderate levels of stress, with 59\% meeting the criteria for clinically significant anxiety and $39 \%$ reporting moderate depressive symptoms. People with a prior mental health diagnosis experienced greater psychological distress. Poor sleep, lower levels of resilience, younger age and loneliness significantly mediated the links between stress and depression, and stress and anxiety [2].

The COVID-19 has rapidly gripped the globe, crippling the healthcare system in many countries. With the rise in workload and the risk of cross transmission of infection to themselves, Healthcare Workers (HCWs) are going through huge psychological stress [3]. India is one of the second largest populated countries in the world and it is quite possible there are so many issues and problems which the Indian society is facing whether it is health infrastructure, medical facilities, transport and education facilities. Majority of the Indian population are living in rural regions and facing lot of problems such as medical facilities, transport and education facilities. The present study is focused on health risk among front liners which they face during COVID-19 crisis.

COVID-19 has led to adverse effects on society as a whole. Everywhere there is a lot of chaos and confusion among the people.
Lakhs of deaths have taken place all over the world which has created fear and anxiety among people. No one is quite sure when this pandemic will end and as such uncertainty is present in the society. It has also crippled the whole economy of the world. People are forced to live within the four walls of their houses. Fear and stress has taken place in society due to the COVID-19 virus which has created so many problems among the people.

This pandemic came suddenly and led to the emergence of various social and economic problems that no one was ready to face. Many developed and developing countries are trying their hard to find a vaccine for this deadly disease, but till now nobody has been successful which has further led to chaos and confusion among people. In India millions of people have been infected due to COVID-19 virus and more than sixty thousand people have died.

In the initial phase of COVID-19, crisis the Indian government was not much prepared to handle the COVID-19 crisis due to the lack of health infrastructure and medical facilities which has directly affected the health of front liners. But with the passage of time, the Indian government has constructed many temporary COVID care center for the victim of the virus. For example: In Delhi, the Radha Soami spiritual center is converted in to COVID care center with 10,000 beds. However, 500 rail coaches were also converted in to 800 beds for COVID victims. It was further observed that many agencies came forward to build COVID care center such as Defence Research Development Organization (DRDO) built temporary hospital of 1000 beds for the COVID victims. Beside the COVID care center, the Indian government have also made own PPE kits for the front liners. 
The study has also observed that the COVID-19 virus is so strong that despite having PPE kits, large number of front liners especially health workers got affected and many of them have died. Every day we see that the COVID 19 virus is spreading very fast in to the society which has led to increase in the magnitude of COVID victims. This has directly increased burden on the health workers and affected their health.

\section{Magnitude of the COVID-19 Victims in India}

As per Indian Council of Medical Research (ICMR) report is concerned India has recorded more than 36.7 lakhs case of the coronavirus till August, 2020 and 65355 people have been died due to COVID-19 virus. It was observed that the magnitude of COVID-19 victims has tremendously increased every day which is leading to the great health risk among common people as well as the front liners who are serving the nation in this critical situation. According to health ministry report, it shows that the recovery rate of COVID-19 victims is 76.61 per cent till August, 2020 and the fatality rate is just 1.79 percent (The Hindu, 30 August, 2020).

The table 1 clearly shows that the magnitude of the COVID-19 victims has tremendously increased every day which has directly affected the health of front liners due to the over burden work and the lack of proper protection. It was observed that the health of the common people got seriously affected due to COVID-19 virus which has led to lot of socio-economic problems in the society. People are not able to earn their livelihood properly due to virus infection and they are constantly living under fear and anxiety. Every day we have seen that more than fifty thousands of people are getting affected due to this pandemic which is the biggest challenge for the medical fraternity as well as the respective state government.

\section{Research Methodology and Objective of the Study}

The present study is based on secondary sources such as research papers/articles, media, and newspaper reports. The main objective of the study is to examine the various issues and problems being faced by the front liners during the pandemic. This pandemic is so huge and dangerous which the Indian society had never witnessed before.

\section{Finding of the Study}

\section{Impact of COVID-19 on front liners}

In the pandemic crisis, front-liners played a dominant role to serve the nation whether it is medical fraternity, police personnel, paramilitary forces, and others who are directly in contact with COVID victims. It was observed that the front liners got tremendously

Table 1: Total number of COVID 19 victims in lakhs (State-wise).

\begin{tabular}{|l|c|c|}
\hline \multicolumn{1}{|c|}{ State } & COVID-19 victims & $\begin{array}{c}\text { No. of Deaths due to } \\
\text { COVID-19 }\end{array}$ \\
\hline Maharashtra & 792541 & 24583 \\
\hline Tamil Nadu & 428041 & 7322 \\
\hline Andhra Pradesh & 434771 & 3969 \\
\hline Karnataka & 342423 & 5702 \\
\hline Uttar Pradesh & 230414 & 3486 \\
\hline Delhi & 174748 & 4444 \\
\hline West Bengal & 162778 & 3228 \\
\hline Bihar & 136337 & 694 \\
\hline Assam & 105774 & 296 \\
\hline Odisha & 103536 & 492 \\
\hline
\end{tabular}

Sources: Deccan Herald, 31 August 2020. affected due to the COVID-19. The family of front liners suffers from additional fear and anxiety as their family members go outside and are in direct contact with the COVID-19 patients. They reported that the front liners are doing their jobs very efficiently, but they are also facing alienation as they are not able to meet their family members for many days.

\section{Health risk among health workers}

During the pandemic it was seen that the role of health workers was very important to deal with this crisis. Without their support and cooperation, it would have been nearly impossible to deal with such an unprecedented situation. They worked day and night to cure the COVID victims without caring for their own lives and their families. It is being seen that day by day the pandemic is on rise and the number of victims are increasing at a fast rate which is directly affecting the health workers as their burden is increasing and there is also a risk to their life.

It was further observed that the Indian government has done a great job by providing the protection kits to the health workers but still they face lot of risk to their lives and the Personal Protection Equipment (PPE) kits are not enough to save their lives. This is greatest worry for the health workers as well as the Indian government. Every day we have seen that many health workers got affected due to this virus. As per the times of India report on 29 August, 2020, in India 87,000 health staff got infected with COVID-19 virus and 573 died among them. It was further seen that there were 74 per cent cases in six states i.e. Maharashtra, Karnataka, Tamil Nadu, Delhi, West Bengal and Gujarat.

However, Maharashtra, Karnataka and Tamil Nadu has tested more than one lakh health care workers each till 28 August 2020. Karnataka reported only 12,260 infected health care workers almost half the burden in Maharashtra. Tamil Nadu reported 11,169 cases that included doctors, nurses and Asha workers. The three states together accounted for 55 per cent of the total cases among health workers.

As per the Hindu report on 9 August 2020 is concerned, in India there were 196 doctors which have died due to COVID-19 virus from the various states include Tamil Nadu is (43 doctors) Maharashtra and Gujarat (23 each state), Karnataka (15 doctors) Andhra Pradesh and Delhi (12 in each state). The Indian Medical Association (IMA) report also stated that out of 196 doctors who lost their lives due to virus, 170 of them were above the age of 50 years with general practitioners attributing to around 40 percent of the death.

It has been observed that if this pandemic continues for a longer period of time say six month or a year it is going to create great risk for the society as well as the medical fraternity. If the health workers continue to get infected like this, then there will be a huge problem for the society. There can be dearth of health workers which will be a huge challenge both for the government and the society. We cannot afford to lose the health workers at this rate during this pandemic. Moreover, there is not any vaccine or medicine till date available to cure the victims. Though various agencies are continuously engaged to develop the same. This all has created a lot of chaos and confusion with in the society and especially among the medical fraternity.

Most of the families of the health workers stated that they are constantly living in fear, stress and anxiety as they family members are in direct contact with the COVID victims and there is a risk for their life. Even the PPE kits are not proving to be enough to protect them and every day many health workers are getting infected and some are losing their lives. The health workers also stated that they are not able to meet their children for so many days as most of the time they are working inside the hospitals. They further added that 
if they got affected due to COVID-19 then what will happen to their children and their future life. They always live in fear and mental stress regarding their family members. The family member of the health workers further stated that they are the worst affected. On the one hand, they are living under stress and fear due to COVID-19, but on the other hand, they have more fear to lose their family members who are working as front liners. In India, there are many studies which has reported similar kind of issues in the pandemic crisis.

According to Roy A, et al. [1], the major mental health issues reported were stress, anxiety, depression, insomnia, denial, anger and fear. Children and older people, frontline workers, people with existing mental health illnesses were among the vulnerable. Discrimination and fear of social isolation due to social distancing worsened by the effects of strict rules of lockdown could add to the cause of their vulnerability. The resulting emotional responses, leading to triggering, relapse or worsening of pre-existing mental health conditions could be another result of the effects of the COVID-19 pandemic. Jagiasi BG, et al. [3] stated that the anxiety, as well as depression, was significantly higher in the group of Health Care Workers (HCWs) who had no support system. Chatterjee SS, et al. [4] reported that doctors had the highest level of anxiety among the healthcare workers. Both doctors and nurses perceived a greater level of irritability than the other HCWs. Compared to doctors and nurses, other HCWs were more likely to experience insomnia. Chatterjee SS, et al. [4] stated that higher levels of perceived stress in female physicians. In contrast to irritability, married HCWs were found to be more hopeless. Concern for family members and their well-being could contribute to their feeling of hopelessness.

\section{Health risk among police and paramilitary forces}

During this pandemic, it was observed that the police and paramilitary forces played a dominant role to maintain the law and order in the society at the time of lockdown. Since, last six months they are working day and night without thinking about their lives to handle the crisis. The study has further observed that majority of the forces are working without proper protection which has directly affected their health. They have just masks and hand gloves to protect themselves which is not enough to save their lives. There is no proper official data about the police and paramilitary forces that how many have been infected due to COVID-19 virus and how many have died. The study has used media report to find out the number of forces infected and died.

As per the Mumbai mirror report on 18 August, 2020, there are 12495 Maharashtra police personnel infected due to COVID-19 and 10111 has recovered and 2256 are active cases. The report further stated that 128 police personnel have lost their lives due to virus. The Hindu report on 20 June, 2020 stated that in Tamil Nadu 1500 police personnel infected across the state. The study has also found that due to the COVID-19 virus the death toll in central armed police forces has risen to 24. The Central Indian Security Forces (CISF) has had seven fatalities, while five deaths have been reported in the Border Security Forces (BSF), eight in the Central Reserve Police Force (CRPF) and two each in the Indian Tibet Border Police (ITBP) and the Sema Suraksha Bal (SSB) (Hindustan Times, 27 June, 2020). The virus has not only affected the health risk of front liners but it also affected their family members. There was one case which reported that after the death of front liner due to COVID-19 their family member also died due to shock. According to mirror new digital report on 12 august, 2020, in Chandigarh 24-year-old woman died of shock hours after the police officer father death due to COVID-19.
It was observed that since, last six months the health risk has tremendously increased among police and paramilitary forces due to the virus. They are working in hostile conditions to serve the nation and protect the people. Without them it would not have been possible to deal with such a pandemic in a country like India with such a huge population. There is uncertainty existing in the society with regard to this pandemic as no one knows when this will end. The forces are working continuously without taking any rest to maintain the law and order in the society. If the virus continues for next six month or a year then it will be a serious problem for the front liners. It is a great challenge for the Indian government to provide proper protection to the front liners so that they can save their own lives as well as the lives of common people.

\section{Health risk among bureaucrats}

In the COVID-19 crisis bureaucrats have also played an important role in the society. It was observed that in the quarantine center they also came in contact with the COVID victims who have directly affected their health. In India, there are number of bureaucrats who have been infected due to the virus and many of them have died. Due to the lack of official data about the infected bureaucrats the study has used media reports which have shown that many bureaucrats have died due to the virus as they were in direct contact with the victims. In Madhya Pradesh there are five IAS officers infected due to COVID-19 virus. They were closely working with state health department to contain the pandemic spread (et. govt.com, July 24, 2020) As per the express news on July 16, 2020 report, 38-year-old bureaucrat died who was tested positive. She was in charge of migrant quarantine center in Bengal. Another case was reported in the Union Territory of Jammu and Kashmir where the Jammu Kashmir Administration Services (JKAS) officer died due to COVID-19 (Tribune news services, July 31, 2020).

\section{Health risk among sanitation workers}

Sanitation workers are also a one of the important part of the society who helps to clean the cities, mohala. They are the ones who make city beautiful by doing their job. But unfortunately, they are not getting much recognition in the society as they come from the marginalized section of the society. During this pandemic they are also working as front liners and putting their life in risk. It was observed that majority of the sanitation workers were working without their proper protection. They were just using mask and hand gloves which put their health in risk. Most of the sanitation workers stated that they don't have much protection kits and they are forced to work without PPE kits. They don't have any knowledge and are not aware about the guide lines given by the central government to the sanitation workers, even most of the sanitation workers don't use hand sanitizer the whole day and are constantly working in the hospitals, COVID care centers and different wards in the society.

The study has further observed that if the pandemic is continuing for next six months or a year then the sanitation workers are going to face great health risk. There is an uncertainty going on in the society and the situation is become worse day by day as the millions of people are being affected due to virus which is a direct burden on the sanitation workers.

During the discussion with the sanitation workers on telephone, majority of the workers stated that they are working in unhealthy environment even in this pandemic situation and they don't have any health insurance. They further stated that if they died due to the virus on duty who will care for their family members. In fact, they are 
working without proper protection kits which have led to health risk and many of them have also lost their lives.

It was seen that many sanitation workers have died due to COVID-19 virus while performing their duty. Due to the lack of official data it is very difficult to find out the magnitude of sanitation workers who were infected or died due to the virus. The study has used media report and tried to find out the sanitation workers who died due to COVID-19 As per the Hindustan Time report on 25 May, 2020, a 45-year-old woman sanitation worker with the east Delhi Municipal Corporation was the second sanitation worker in Delhi to succumb to COVID-19. She was deployed on road cleaning duty in the Raghuwarpura ward near Gandhi Nagar. Another case was also found in North Delhi Municipal Corporation where a 53 years old female sanitation worker died of COVID-19. The worker was deployed in Timarpur ward of the civil line zone (Hindustan Time. July 7, 2020). Similarly, other case was also found in Delhi where a sanitation worker employed with South Delhi Municipal Corporation died of COVID-19 (TOI, 31 May, 2020) In Delhi at least 15 sanitation workers have died and 40 have been tested COVID positive. The President of Delhi safai karamchari union said that after the COVID-19 outbreak every house, road side and drain has discarded masks, gloves and face shields. Even if one of these items belongs to a positive person the sanitation worker who is handling it will also contract the disease. As the number of cases increases this problem will get bigger and it will be our sanitation workers who will lose their lives. They call us CORONA warriors, but the truth is that they are sending us to this war with no weapons and eventually such a warrior succumbs to the enemy (H.T. 13 June, 2020) India Express on 28 may 2020 reported that 1529 front liners of Bombay Municipal Cooperation (BMC) workers got infected and 25 have died.

According to Roy A, et al. [1] the frontline workers including doctors, nurses, community health workers, sanitation workers, policemen, and other volunteers across the world are in an entirely unprecedented situation, having to make impossible decisions and work under extreme pressures. Working under stressful conditions with scarce resources affects not just their personal and family life, but also place them in a situation of moral injury, causing mental health problems.

\section{Attitude of the community towards front liners}

The community plays a dominant role of hegemony in the society whether it is socially or economically. But during the pandemic crisis, it was seen that the community turned hostile towards COVID-19 victims who died due to CORONA. The community did not allow people to perform the last rites of the CORONA victims who died. This is a very strange thing seen in the society that the community showed a hostile attitude towards the dead body. Most of the community members are living in fear that if the dead body of the CORONA victim is buried or cremated near them, the disease might spread to them. So they are constantly living in a fear/trauma and opposed to perform the last rites of the dead body. It is seen that if this pandemic continues for a longer time, it may have adverse effects on society and the community in particular. One community may start hating the others due to the hostile attitude. In India, it was observed that in many cases the community members were opposed to performing the last rites of the COVID victims. As far as Indian express report on 17 April 2020 is concerned, it shows that in Meghalaya a 69 years old physician and founder of one of the first big private hospitals of the state was buried at a church cemetery, almost 36 hours after he died. The report further stated that the family wanted to bury him in Nongpoh, where they own a house. But residents and community leaders refused, citing the virus spreading. Another similar kind of incident has been observed in Chennai where a doctor died due to CORONA, and people refused a proper burial and protested at the cemetery where his body was taken. As the mob pelted stones and attacked the ambulance, his colleagues had to dig a grave with bare hands to bury the doctor (India Today, 17 April 2020).

It is seen that the community feeling has been lost during this pandemic crisis. Fear has engulfed the people and all are just thinking about themselves. Nobody cares about the welfare of their community members especially those who lost their lives during the pandemic. Their dead bodies are being treated very badly, without any dignity by their community. Community and we feeling which was an essential aspect in Indian communities and which was a mark of identification has been totally lost during this crisis.

\section{Conclusion}

From the above discussion, it can be concluded that the pandemic has created so much panic, fear, and anxiety in the society that the people have faced so many problems socially as well as economically. In the pandemic crisis, it is the front-liners who are facing great risk for their life as they are ones who are in direct contact with the COVID-19 victims. Even their family members are at greater risk. Since, last six months it has been seen that the front liners are working day and night to save the COVID-19 victims. But unfortunately, without proper protection they are at a greater risk to lose their lives. Their contribution in the present crisis is tremendous and the society as a whole cannot ignore their efforts to save the nation. For many years to come our country will remember their contribution and their selfless services for the nation. The study has also observed that with in a society people have forgotten their norms and values due to the fear of virus and they show their hostile attitude towards COVID-19 warriors as well as victims of the virus who have died. Community is feeling and we feeling which an essential aspect in Indian communities was and which was a mark of identification has been totally lost during this crisis. In India, it was observed that every day nearly about one lakh people are being affected by this pandemic which is putting an additional burden on COVID-19 warriors especially the medical fraternity. There is chaos and uncertainty existing in the society due to this virus and people are living in constant fear and anxiety. Many scientists and medical agencies are working tirelessly to find out vaccine for this virus. But unfortunately till now they have not been successful which is creating of stress and anxiety in the society. If this condition prevails for next six months or a year then the society and the medical fraternity are going to face a great challenge.

\section{Declaration of Conflicting Interests}

The author declared no potential conflicts of interest with respect to the research, authorship and/or publication of this article.

\section{Funding}

The author received no financial support for the research, authorship and/or publication of this article.

\section{References}

1. Roy A, Singh AK, Mishra S, Chinnadurai A, Mitra A, et al. (2021) Mental health implications of COVID-19 pandemic and its response in India. Int J Soc Psychiatry 67: 587-600.

2. Varma P, Junge $M$, Meaklim H, Jackson ML (2021) Younger people are more vulnerable to stress, anxiety and depression during COVID-19 pandemic: A global cross-sectional survey. Prog Neuropsychopharmacol Biol Psychiatry 109: 110236. 
3. Jagiasi BG, Chanchalani G, Nasa P, Tekwani S (2021) Impact of COVID-19 Pandemic on the Emotional Well-being of Healthcare Workers: A Multinational Cross-sectional Survey. Indian J Crit Care Med 25: 499-506.

4. Chatterjee SS, Chakrabarty M, Banerjee D, Grover S, Chatterjee SS, et al. (2021) Stress, Sleep and Psychological Impact in Healthcare Workers During the Early Phase of COVID-19 in India: A Factor Analysis. Front Psychol 12: 611314. 